\title{
Discussion on the Social education of contemporary college students' socialist core values
}

\author{
Wu Xiaolin ${ }^{1, a}$ \\ ${ }^{1}$ Hunan University of Science and Technology, Yongzhou, Hunan, 425100 \\ a987372572@qq.com
}

Keywords: college students; values education; social education

\begin{abstract}
The social education of contemporary college students' socialist core values is from a broad perspective to explore the issues related to the contemporary college students' values education: Firstly, what kind of relationship exists between the contemporary college students' values education and social education. Secondly, why the social practice is the most important in college students' values education. Thirdly, in the sight of social education, how to perfectly achieve the contemporary college students' values education.

Socialist core value system is the soul of rejuvenating, determines the development direction of the socialism with Chinese characteristics. It clearly states in the eighteenth congress of the communist party of China: "advocating prosperous, democratic, civilized, harmonious, and advocating freedom, equality, justice, the rule of law as well as promoting patriotism, dedication, integrity, kindness, and actively cultivating and practicing the socialist core values." [1]. College students' core values is not only an important content and aspect of the socialist core value system, but also the cornerstone and guarantee of that socialist core value system can be gotten a genuine and effective implementation in the future in the land of China. College students' values education is both a comprehensive concept, but also a complex system engineering. Whether as a theoretical concept, or as a practical project, which is composed of multiple dimensions- namely social, schools and individuals. The social dimension of contemporary college students' values education is from the perspective of the general social (including the family, the family is the cell of society, is the basic organizational unit of society) to explore the following issues related to the contemporary college students' values education: Firstly, what kind of relationship exists between the contemporary college students' values education and social education. Secondly, why the social practice is the most important in college students' values education. Thirdly, in the sight of social education, how to perfectly achieve the contemporary college students' values education. Around these issues, the specific discussion in this article is started.
\end{abstract}

\section{Social education is a short board of contemporary college students' values education}

Social education is defined as that in order to promote the comprehensive development of people and social progress, the society adopts various purposeful, planned and organized educational practices [2]. It includes the following meanings: firstly, social education has a distinct educational and countermeasures, it not only improves the populace's cultivation, but also even more helps to solve social and education problems. Secondly, the subject of social education is multi-element. All members of society is as the object in social education, as long as the subject who exerts influence on all members of society are the main implementing body of social education. Thirdly, the object of social education is extensive. Fourthly, social education is content-rich and openness. Social education not only has no limitation of age, time and place, but also is able to communicate the education with social life, production and labor, leisure and entertainment, etc., it breaks the inherent closure of school education, with great openness and richness. Fifthly, the form of social education is various. Sixthly, social education has compensatory. Social education is not only face to the school, but also face to society; not only to compensate for the lack of school education, but to meet the needs of adults' continuous learning. Seventhly, the field of education community is broad. 
Social education is an important area of contemporary college students' values education. Human is a social animal. If contemporary college students want to become integrated man, they must integrate into the society, and also needs the guidance of social education. Social education is a bridge link between individual and society. Social education is used to develop independent personality for personal, while individuals become to the part of society at the same time. From the perspective of social individuals, the acquisition of college students' values needs social education to achieve. "The essence of human is not the inherent abstraction of a single person, in its reality, it is the sum of all social relations" [3]. "At any times, conscious is only the existence to be aware, and the existence of people is their real life process. ...... It is not that the conscious decide to live, but life determines consciousness" [3]. As the central position in people's consciousness, values can only be obtained from the person's real life, and social education is a very important way for people to get values.

Although social education is an important area of contemporary college students' values education, which plays an important role for the formation of college students' values, in real life, sighted people often driven by the "Matthew psychological", and they habitually more prefers and cares for school education. Thus, social education has become a short board of contemporary college students' values education.

It mainly manifests in the following aspects: firstly, the concept of social education lacks to pay attention, and social education becomes a dispensable part of contemporary college students' values education. In China, the school education appears very early, has a long history and tradition. However, the true sense social education only appeared in modern times, and is an "Exotic matter" and therefore, the majority of Chinese people in the heritage and edification of long history and culture and they have long been familiar with the school education. However, the deplorable is that only a few people really know what property of social education is. In most Chinese people's world of the concept, the social education is a hollow concept and unnecessary waste. Just because of this reason, for a long time, under the aegis of school education, social education are struggling to survive, school education seems to replace the contents of the social education, and oversteps the boundaries should be abided, constitutes the entire of Chinese education. However, this is not true. No doubt, school education is important, but it cannot replace the social education. School education is mainly a transfer of knowledge, the major concern and exploration of school education is the intellectual problem such as right or wrong, true and false, etc. in epistemology, while the value problems such as good or bad and their evaluation criteria, the cultivation of wisdom, the attention of soul, care for life in axiology are rarely mentioned. However, human is a unity of rational and value. as the existence of intellectual people, it needs to constantly learn in order to master the laws of the objective world, as an existed value, people not just stick to knowledge reservation like right and wrong, true and false, but also dedicate to the pursuit of values, such as good and evil, beauty and ugliness, therefore, social education is indispensable. Accordingly, the growth of college students is both inseparable from the accumulation of knowledge, but also is inseparable from the culture and shaping of values. Knowledge and value for every rational beings are essential, only if organic combination of both, the prerequisite of rational beings to pursuit happiness can be guaranteed. If they neglect to life, live, the values cognition and caring of soul's goodness and beauty, then the objective knowledge grasp of the outside world will lose its ultimate meaning. Therefore, from the perspective of that knowledge and values are inalienable, both the social education and school education are the integral part of contemporary college students' values education.

Secondly, the distribution of educational resources is uneven, the basic of social education is weak, and it is difficult to give play to valueseducation in college. Social education needs of the social education resources. Someone think that social education is the school education, and from this prejudice, they believe that social education resources is the sum of all the material resources and spiritual resources of the school education activities, and based on this, social education resources are divided into five categories: facility resources, human resources, financial resources, literature resources and organizational resources. Who hold this view is not unusual, in this, the 
school education has become a synonym for social education, and the so-called social education resources have been firmly confined within the narrow range of resources which can be taken advantage in the school, that means outside of school it no longer exists social education resources, which is obviously a one-sided view, under the guidance of this view, more social resources are put into the schools in which have relative abundance of educational resources to devote naturally become a matter of course, resulting in the uneven distribution of educational resources, waste and unused of school education resources but shortage and stressed of social education resources, this view has greatly restricted the normal development of social education. Therefore, in the increased urgency background of the needs of college students' values education, social education is difficult to play its due role.

\section{The combination of education and influence is the key of contemporary college students' values education}

Values education is a process of the combination of passive "teaching" with active "learning". contemporary college students' value cultivation not only needs the passive teachings and edification, but also needs active learning and inspiration, therefore, contemporary college students' values cultivation needs to combine the rigid "education" with soft "influence", the combination of education with influence each other is the key to the contemporary college students' values education.

Educational method is as the goal, social education can be divided into two forms of social education and social influence. Social education is the social education method with repressive, spoon-feeding and the main form of preach, mainly through external control power for actors to generate constraints and pressures, and make the actors who cannot dare to violate social norms and morals, thus forced to accept the mainstream ethics and values; so-called social influence is the social education method of that educators have a purpose and a plan to help the emotional nature and a good environment and atmosphere to emotionally touch the educatee, in order to deepen or transform original thoughts, emotions, it is mainly taken the ways of love moving, emotional contagion, nurturing environment, etc.. Social influence is the criteria of value and moral code of society or groups, mainly through internal controls power to make members of society consciously accept and internalize the life in it. Social education and social influence are two important elements of contemporary college students' value education, they cannot be entirely left to cut, but also cannot ignore the differences between the two.

Social education and social influence of values exist differences in educational material sources. The content of social influence of values mainly from the commands and teachings of superiors, elders and authority of the organization, it is a social education method of top-down, relatively single content, the general performance is the monotony specification writing, preaching and publicity. The content of social influence of values is mainly from the heard and feel of the society members on criteria of value and moral culture concepts, it is a potential emotional communication, namely the often referred emotionally moving. Therefore, this education can be both top-down and can be carried out in parallel, and can also be bottom-up.

The position of college students in social education and social influence of values is different. In most cases, the social education of values is other control process, and social influence is the self-control process. So, college students who can accept the social education of values are under the control of outside forces, mostly reluctantly accept social education of values. In this process, college students are passive. If the content of social education of values want to reach to their internalized thing, it is still very difficult. The students accepted social education of values under the infection of inherent control, internalize the educational content of values to their voluntarily standard, college students in the process is easy and no conflict, they are active.

The implemented effect of social education and social influence of values has a significant difference. In the process of social education of values, college students often manifest in the offensive, rebellious mood, although someone have superficially accepted, in the heart is displeasure. So there will be appeared that the more the content of values education is, the worse the 
received effects are, so the social education of values will enter an embarrassing link (stagnation or retrogression). The social influence of values through the emotion collision the infection of atmosphere to affect the students, it is a kind of love and good education. It unconsciously been argued. The former dogmatized standard and preach is internalized into its own qualities and personality, which will produce its pursuit the value of love and good behavior in society.

In the whole process of making social values education, social education and social influence of values coexist, and it is indispensable, but the circumstances of both when applied are different. When do it need to use the social education of values, when do it need to use the values of social influence, and under what circumstances require a little more social education of values, under what circumstances need a little more social influence, because these are things vary from person to person, it needs to follow an alternative principle. In short, the social education of contemporary college students' values needs pay attention to the educational method, in which education and influence are combined with each other, and under the combined action of internal and external causes, shaping values is worthy of a role in an effective method, whether the method can be skillfully used is the key to get the effect of half the work with double results in college students' values education.

\section{The social practice is the focus of contemporary college students' values education}

As mentioned earlier, social education is an important area of contemporary college students' values education. So, how can we be better to make values education in the field? This is a question of that social practice needs to answer, and only social practice can well solve this problem from the roots.

After analyzing the pros and cons of various contemporary values education model, America's moral educators Fred Newman considers that many contemporary values education are more emphasis on getting students to master the theory, while ignoring the cultivation of their ability to participate in social action. He believes, values clarification model emphasizes the cultivation of students 'ability to distinguish the value, it requires students to follow their own recognized values to deal with the various problems encountered in life; the emphasis of values cognition development model is to promote students' consistent judgment on moral behavior and moral cognition based on rapid developing students' moral cognition and ability of judgment, to create conditions for students' moral action. While, their characteristics are committed to making students to obtain more value, ethics and other aspects of knowledge, but neglect the cultivation of students to participate in social practice ability. To overcome these shortcomings and make up for its shortcomings, Newman made his social practice mode of values education.

In Newman's social practice mode, "environmental capacity" is an important concept, it is defined as the action capability of a particular consequences caused by human to environment, which consists of physical ability, interpersonal competence and the civic competence. Physical ability is the ability to affect the object, including the aesthetic ability (such as painting, etc.) and functional capacity (such as building a house, etc.); interpersonal competence refers to the ability of the human's impact, including the ability to cultivate relationships (such as caring for friends, etc.) and economic relations capabilities (such as buying a car, house, etc.); civic competence refers to the ability to influence public affairs, including the capability in public election process (such as helping a candidate win the election, etc.) and the ability in interest groups (such as how to change the preferential policies for consumer and protect own groups, etc.). Newman believes that the key of values education is to cultivate the environmental ability, especially practical ability.

The key of values education is to train college students' social practice ability, which is to culture the college students to become a "moral actors". In real social life, it inevitably exists some immorality phenomena or conflicts, but some students may think that this has nothing to do with their own, some students may think that they have no ability to influence or change this social phenomena, so the existence of these moral issues in the society are ignored. Newman believes if it wants college students to get active attention to these issues, college students should be cultured to a "moral actors", that is to raise the enthusiasm, initiative and sensitivity of them to moral issue, 
their capacity for environmental effects, and initiatively make appropriate action to influence and change society.

Newman's social practice values education model emphasizes through students' social action cultivation, it aims at increasing students' awareness, the ability to investigate and solve social problems, which gives us a new perspective of a values education. Social practice values education model emphasizes the college students' understanding of social issues, focus on training students' moral behavior. Meanwhile, the new values education system based on the principle of system science, of combining philosophy, psychology, sociology, literature and other disciplines in one is proposed, which emphasizes the combined effects of various disciplines to students.

In short, only in social practice, students are enable to understand the society, and thus integrate into the society and raise their awareness, the ability to study and solve social problems. Only in social practice, individual's ethical behavior attainment of students can be improved, to make up for other deficiencies of values education, but also further develop and improve the implementation method and principle of college students' values education in social practice, to ensure that college students' values education to achieve tangible results.

Fund program: initial results of Hunan Province Education Science "Twelfth Five-Year Plan" funding issues " research on the construction of socialist core values and contemporary college students' values " (Item Number: XJK012BDY013); research results of Hunan Province Political Research Base in Hunan Institute of Science and Technology.

\section{References}

[1] Hu Jintao's eighth report on the National People's Congress of Chinese Communist Party. 2012,11,8

[2] Gong Chao, Shang Herui. The exploration of social education concept [J]. Zhejiang Social Sciences, 2010, 3:84

[3] Marx and Engels anthology, 2nd Edition, Volume 1 [M]. People's Publishing House, 1995:60

[4] Marx and Engels anthology, 2nd Edition, Volume 1 [M]. People's Publishing House, 1995:30 = 